\title{
CAN MOSQUE FUND MANAGEMENT FOR COMMUNITY ECONOMIC EMPOWERMENT? : AN EXPLORATORY STUDY
}

\author{
RB Dandy Raga Utama ${ }^{1^{*}}$, Zavirani Fitrandasari ${ }^{1^{*}}$, Moh. Arifin ${ }^{2^{*}}$, Ridan Muhtadi ${ }^{3^{*}}$
}

\section{* Affiliation: \\ ${ }^{1}$ Faculty of Economics and Business, Universitas Airlangga, Surabaya, Indonesia. \\ email: \\ rb.dandy26@gmail.com zaviranifitrandasari@ gmail.com \\ ${ }^{2}$ Postgraduate School, Universitas Airlangga, Surabaya, Indonesia arifin.dzulqornaen@gmail. com \\ ${ }^{3}$ Islamic Economic Departmen, STAI Miftahul Ulum, \\ Pamekasan, Indonesia ridanmuhtadi@gmail.com}

\begin{abstract}
:
The actual meaning of the mosque is not limited to a place of prostration but all activities that draw closer to Allah. Mosques as one of the centers for fostering and developing Islamic societies occupy an important role in the process of social change and support the acceleration of development in modern societies, especially in developing spiritual aspects. Mosque prosperity is not only limited to physical development in a state that is beautiful and as grand as possible, but also must be supported by the development of a broader understanding of the function and role of mosques as Islamic social institutions. This research is qualitative research by raising the phenomenon of mosques that carry out productive activities in order to prosper the community. This study uses a phenomenological approach. The object in this study was the Ummul Mu'minin Surabaya mosque. Data collection techniques used observation, interviews and documentation by making takmir and the community as key informants and key informants. The Ummul Mu'minin Mosque is able to maximize the function and role of the mosque optimally. The potential of a mosque that is so great as a place for solving problems in the economic field has been well proven. The mosque funds collected from donors are managed properly and correctly.
\end{abstract}

Keyword: Mosque Fund Management, Economic Community Empowerment

\section{INTRODUCTION}

Mosques as public property of Muslims have great potential in funding and lending for the benefit of the community's economy. This potential requires management of the management of mosque funds that are good in order to optimize the role and function of the mosque. Moreover, the management of mosques in both rural and urban areas has become a prolonged polemic, because one of the weaknesses is that management of mosque management is passive and tends to be less active. 
Management of mosque fund management in question is an activity or activity to regulate the use of resources for the achievement of a common goal of prospering the economy of the community. One of the strategies to prosper the community through empowerment. Istan (2017) states that community empowerment is "helping clients (empowered parties), namely the needy and poor (poor) so that they get the power to make decisions and determine the actions they will take to improve their lives, including reduce the effects of personal and social barriers through increasing their welfare.

Management of mosque fund management will involve other people effectively and efficiently which consists of actions of planning, organizing, regulating, compiling, mobilizing, controlling, controlling and so on so that what is planned can run well and maximally according to the business and potential that there is. In the modern era the mosque experienced degradation of roles and functions, during the time of the Prophet Muhammad, the mosque became the center of all activities (Kurniawan, 2014). Even though community problems are increasingly complex, especially in the economic field.

Such great potential must be managed with good and professional. Some structured programs will not be achieved properly if they are not supported by sound and strong finance (Sochimin, 2016). The management of the mosque will include planning, organizing, implementing, controlling, and monitoring human resources and financial (human and financial resources) of a mosque to achieve its objectives (objectives). Mosque economic empowerment is a very strategic program in order to assist government programs in improving people's welfare. The mosque, as an entity that directly touches the grass root community, must have maximized its role. So it is necessary to know how the management of labor funds in empowering the community economy? Because there are mosques that have large funds but grow with unclear programs, but there are mosques that have little funds but are aggressive in the economic development of the people.

\section{THEORETICAL FOUNDATION AND PROPOSAL DEVELOPMENT Fund Management}

Management is the process of planning and decision making, regulating, leading (directing) and controlling an organization to achieve effective and efficient success (Ilyas, 2001: 10). Trust in public funds that provide to mosques must be able to be managed effectively and efficiently. Therefore, there is a need for management of mosque funds so that the funds managed can be right and have a multiplayer impact on people's welfare.

Activity funds can be obtained through charity envelopes, charity boxes, and recipients of tetatp donors. Such methods are still fairly classic, in the era of information technology, fundraising can be done with barbarians such as holding a charity bazaar, conducting building auctions, selling charter, selling calendars, and holding shows (Ayyub 1996: 151). Can also collect through the internet by utilizing social media.

Funds collected will be distributed according to community needs. The distribution will be regulated by a systematic and structural financial management because the funds raised are the mandate given to the mosque for the benefit of the community. Indriyani in Waluyo (2017) said that funds are assets or activities needed to carry out activities both consumptive and 
productive. Thus, management of mosque funds can be used through a system of controlling and utilizing all factors, both human resources and natural resources for the sake of effective and efficient management.

\section{Mosque Terminology}

Muslim communities regard mosques as places that have high spiritual value. Mosques (mosques) are houses of worship for Muslims. In the surah At Taubah (18) the concept of the mosque refers to the mosque that belongs to Allah, which is prospered by the servants of Allah who believe in Allah and the day after (the Resurrection, and the period in the Hereafter). In the letter of Al Jin (72) affirms that "Indeed the mosques are God's property because do not worship other than Allah" (RI Department of Religion, 470). If correlated with the world of mosques is not only a place of prostration, but the mosque has a more universal meaning that is related to all human activities that reflect obedience to Allah SWT.

In the surah Al-Baqarah verse 114 is the threat of Allah to those who prevent others from worshiping Allah in His mosque, and also try to tear down the mosque. The definition of destruction can be in the form of misuse of funds that have been entrusted to the mosque. thus, mosque funds must be managed properly, not only consumptive but must be productive in order to have multiplayer effects on people's lives.

\section{Mosque Economic Development}

Economic empowerment of ethrus communities is carried out. Religious institutions are expected to be an alternative so that the Islamic economy can be realized. Empowering the mosque-based economy can be realized by utilizing zakat, infaq, alms, endowments, grants and other philanthropic funds. Community economic empowerment needs to be done because seeing the condition of the majority of the economy of the people who are weak, it needs a strategy to make changes towards a stronger economy.

Economic empowerment is a form of economic preaching so that people's welfare can be realized. Because mosques have a function of social services for the community such as health, education and the economy as well as being a solution for existing social problems such as poverty (Rahmawan, 2013). One important factor in determining the prosperity of a society is seen from the level of income. With the existence of a mosque empowerment program, it is expected to be able to increase people's income, so that there is a need for professional fund management.

\section{RESEARCH METHODS}

This research is qualitative research by raising the phenomenon of mosques that carry out productive activities in order to prosper the community. In this study researchers are required to focus more on the basic principles of phenomena that occur in social life, which will later be analyzed using existing theories. This study uses a phenomenological approach.

The object of this research is the Ummul Mu'minin Surabaya mosque which has implemented economic empowerment for the prosperity of the community. Data collection techniques used observation, interviews and documentation by making takmir and the community as key informants and key informants. Van Kaam in Jannah (2016) states that 
phenomenological data analysis techniques have a series of procedures as follows: first, list the initial grouping of data obtained. Second, reduction and elimination. Third, group the remaining data from the elimination process. Fourth, final identification of data obtained through initial data validation. Constructing textual definitions from informants so as to produce meaning and essence of research problems.

\section{DISCUSSION AND RESEARCH RESULTS}

\section{Profile of Mosque Economic Empowerment}

It can be seen that the Ummul Mu'minin mosque carried out community empowerment activities through soft loans to the community. Empowerment is in the form of business capital assistance to increase people's income and avoid ribawi practices. As a religious institution that always tries to keep up with the times, the principles of managing the Ummul Mu'minin Mosque are set as follows: First, vision "As the largest mosque in the Baratajaya Village Gubeng Sub-district, Surabaya City, the Ummul Mu'minin Mosque is managed to be the best mosque in the implementation of Islamic Shari'a and Mu'amalat in this region ".

Second, the mission, In an effort to achieve its vision, the Ummul Mu'minin Mosque is managed based on 3 principles, namely: Trust, Trustees can be trusted sayings and actions, and always hold the mandate correctly in accordance with Islamic law and applicable legislation. Professional, Works in accordance with an effective and efficient management system (ie doing the right thing in the right way). Transparent: Carrying out an integrated and open control system at any time is always ready to be examined internally and externally, and always provide regular reports (Ummul Mu'minin mosque documentation, 2018).

As a religious institution that acts as a recipient, user and distributor of zakat, infaq and shadaqah funds, it must always comply with the provisions regulated by the government in law number 23 of 2011 with the principle of transparency. The birth of Law No.23 of 2011 provides an opportunity for mosques to become a place to improve people's welfare. With the enactment of the law, de facto and de jure mosques were designated as religious institutions capable of managing Islamic philanthropic funds. Opportunities to restore the welfare of the community through mosques are wide open by optimizing the collection and distribution of zakat, infaq and charity funds through professional human resources.

\section{Description of Mosque-Based Community Economic Empowerment Draft}

Figure 1 below is a draft of the mosque fund flow to the community based on the results of interviews with the management of the Ummul Mu'minin mosque. The flow is a phenomenon in the field obtained during the research. Following is the flow of the distribution of empowerment funds at the Umm Mu'minin mosque: 


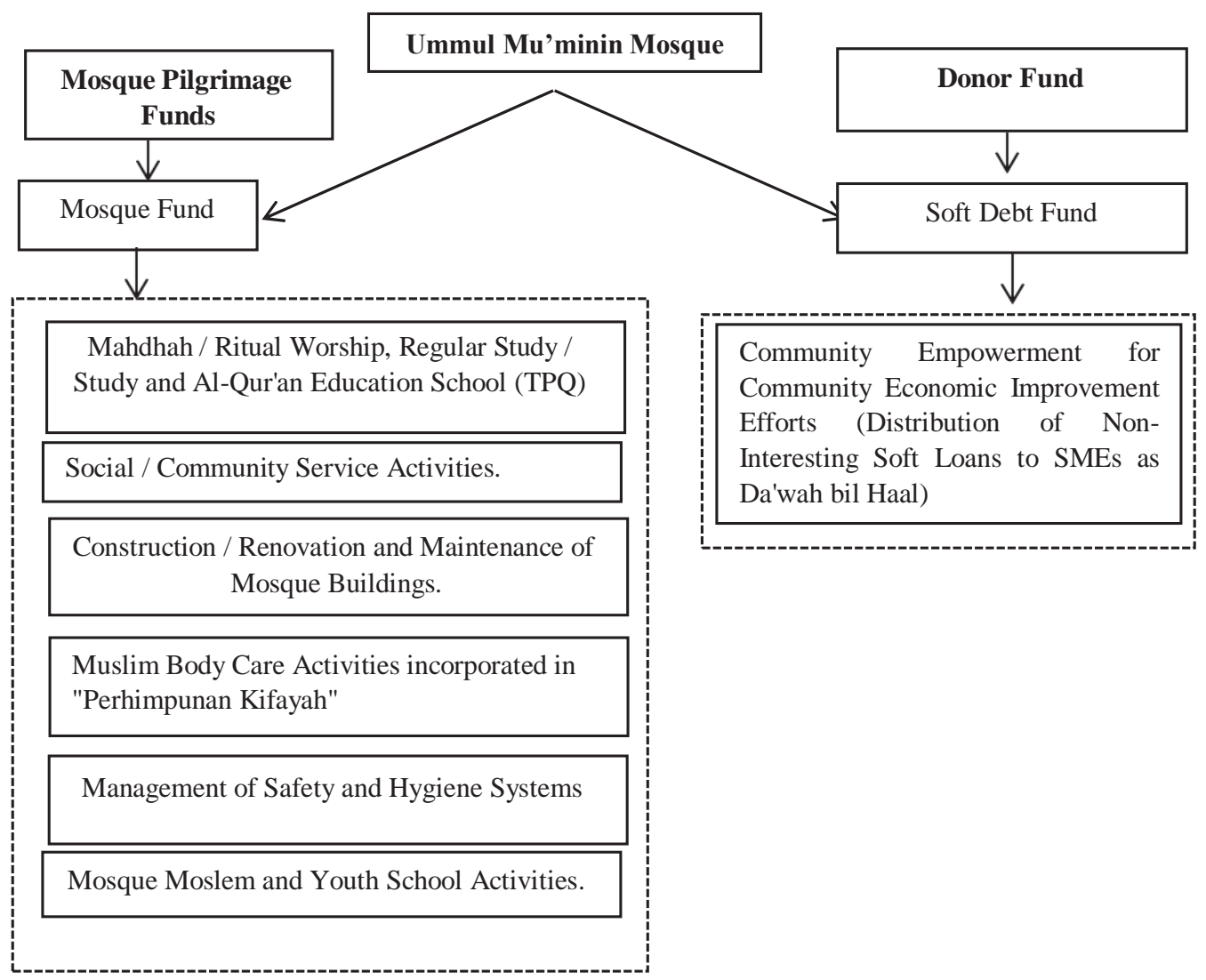

Source: Results of interview, 2018 (processed).

Figure: 1

\section{The Distribution Of Ummul Mu'minin Mosque Funds}

In the picture above it can be understood that the Ummul Mu'minin mosque has two financial management such as the source of funds and the distribution of funds. The source of funds given to the mosque will be managed for consumptive activities based on the needs of the mosque and the community. Funds obtained from donors will be distributed to productive activities. According to Qomari (2018) funds obtained from donors will be distributed to people who lack capital, this is done to improve the practice of ribawi.

Regarding revolving loans without interest, it is certainly different from loans in general. People who get soft loans must return to the management of the mosque as the fund manager as much as borrowed funds without any additional and deductible. Related to the provisions of the amount of funds and business groups that will be funded, they are submitted based on the type and size of business capital requirements. In this case, the mosque administrator has full authority in determining the amount of the loan that will be given to the community. In accordance with the agreement, all initial loans are given starting from Rp. 200,000, - (considered an increase in accordance with the field of business), business development and smoothness in installments will be a consideration to get a larger loan, namely: Rp. 400,000-Rp. 600,000 - Rp. 800,000 - Rp. 1,000,000 (Documentation of the Ummul Mu'minin Mosque, 2018).

The Ummul Mu'minin Mosque provides easy access to capital for people who have difficulty developing businesses due to limited funds. The ease of access by the community is an 
advantage that can be developed because with the function of the mosque as a place of worship that is always visited by the ummah, it provides an opportunity for the economic development of the people (Erziaty, 2015). Well-managed economic empowerment of mosques will have an impact on the economy of society. Hutomo (2000) states that the practice of empowering the current economic sector includes: first, revolving capital assistance; second, infrastructure development assistance, third, local institutional development, fourth, strengthening and building business partnerships and fifth, facilitation from facilitators. According to Qomari the mosque administrators not only provide business capital assistance but also provide entrepreneurs such as supervision, supervision and motivation to the community so that the business being run becomes developed. Education is considered important not only for recipients of business assistance but also for empowerment agents so that the expected outcomes can be maximized.

\section{Management of Mosque Fund Management in Economic Empowerment}

Mosques that have applied economic empowerment to the community certainly have good management practices. Management consists of aspects of fundraising and distribution of funds. Understanding the socio-economic reality of the community around the mosque is the main capital for administrators to manage more professional funds. The distribution of productive funds will be right on target so that it can narrow the gap between the rich and the poor.

Based on the results of interviews with Ummul Mu'minin mosque administrators there are some interesting points that can be found, namely: First, the beginning of mosque funds used for productive activities comes from the personal funds of the mosque administrators. second, after the implementation of non-flexible soft loans, mosque administrators conducted interactive communication to their colleagues to donate part of their wealth to the mosque. funds collected from donors will be distributed in productive activities. Third, non-flexible soft loans are distributed to the people who have businesses and do not have an effort for the implementation of social justice for the community.

Fourth, mosque administrators explore the economic potential of the community in order to be able to increase their income. Fifth, mosque administrators provide assistance to people who receive business assistance. The findings were representative in describing the implementation of economic empowerment at the Umm Mu'minin mosque. The administrative process to obtain business assistance is very flexible, but the community must enter into an agreement to return all forms of loans given. For people who have a good installment history, there is a potential for the amount of loans to be added in the next period.

According to Hermawan K. Dipojono in Sochimin (2016), one of the reasons mosques are demanded to be pro-active in contributing to society is to solve problems that are reached by the community, especially in the economic field. Mosques have potential, both tangible and measurable. intengible (not measurable) to contribute in solving problems that arise in the community. The most crucial problem in the community is the lack of business capital so that the majority of people are forced to use the services of moneylenders so that they are trapped by ribawi practices.

Mosques must be pro-active not only to realize consumptive activities but also to carry out productive activities. Thus, the mosque was not only prospered by the community, but 
also the mosque was able to prosper the community. So that there is a mutualism symbiosis between the community and the mosque. Prospering the community to be able to use mosque funds collected from the community, the funds are managed using professional management to provide optimal results.

\section{CONCLUSION}

The Ummul Mu'minin Mosque is able to maximize the function and role of the mosque optimally. The potential of a mosque that is so great as a place for solving problems in the economic field has been well proven. The mosque funds collected from donors are managed properly and properly by professional staff. Fund management is related to the process of collecting and distributing public funds. The funds used by the Ummul Mu'minin mosque for non-interest soft loans are obtained from donors who are willing to provide their assets for productive activities. The mosque management as an empowerment agent then manages the funds for productive activities. In other words, the funds were distributed to people who lacked capital so as not to enter into ribawi practices.

\section{REFERENCE}

Ayub, Moh. E. Dkk. (1996). Manajemen Masjid. Jakarta : Gema Insani Press

Erziaty, Rozzana. (2015). Pemberdayaan Ekonomi Potensial Masjid Sebagai ModelPengentasan Kemiskinan. AL-IQTISHADIYAH Jurnal Ekonomi Syariah dan Hukum Ekonomi Syaria, ISSN Elektronik: 2442-2282 Volume: 2, Nomor 2.

Ilyas, Al-Wahidi. (2001). Manajemen Dakwah, Kajian Menurut Perspektif Al-Qur'an. Yogyakarta : Pustaka Pelajar.

Istan, Muhammad(2017) Pengentasan Kemiskinan Melalui Pemberdayaan Ekonomi Umat Menurut Persfektif Islam. Journal Journal of Islamic Economics, Vol. 2, No. 1. E-ISSN: 2548-3102, P-ISSN: 2548-2343.

Jannah, Nurul. (2016). REVITALISASI PERANAN MASJID DI ERA MODERN (Studi Kasus di Kota Medan). Tesis, Pascasarjana Reguler Ekonomi Islam Universitas Islam Negeri Sumatera Utara Medan

Kurniawan, Syamsul. (2014). Masjid Dalam Lintasan Sejarah Umat Islam. Jurnal Khatulistiwa - Journal of Islamic Studies Volume 4 Nomor 2 September.

Mardi Yatmo Hutomo, "Pemberdayaan Masyarakat dalam Bidang Ekonomi: Tinjauan Teoritik dan Implementasi", makalah disampaikan pada Seminar Sehari Pemberdayaan Masyarakat yang diselenggarakan Bappenas, tanggal 6 Maret 2000 di Jakarta.

Rahmwan, Feri. (2013). Fungsi sosial masjid terhadap masyarakat (studi kasus di masjid alhidayah purwosari, sinduadi, mlati, sleman). Skripsi. Jurusan Ilmu kesejahteraan Sosial, Fakultas Dakwah dan Komunikasi, Universitas Islam Negeri Sunan Kalijaga Yogyakarta.

Sochimin (2016). Manajemen Keuangan Masjid Berbasis Pemberdayaan Ekonomi Umat. Jurnal Ekonomi Islam (Islamic Economics Journal), Vol. 4 No. 1 